\title{
Determinants of Leadership Style in Big Five Personality Dimensions
}

\author{
Hamid Hassan ${ }^{1, *}$, Sarosh Asad ${ }^{1}$, Yasuo Hoshino ${ }^{2,3}$ \\ ${ }^{1}$ FAST School of Management, National University of Computer and Emerging Sciences, Pakistan \\ ${ }^{2}$ Graduate School of Business Administration, Aichi University, Japan \\ ${ }^{3}$ Graduate School of Systems and Information Engineering, University of Tsukuba, Japan
}

Copyright $\mathrm{O} 2016$ by authors, all rights reserved. Authors agree that this article remains permanently open access under the terms of the Creative Commons Attribution License 4.0 International License

\begin{abstract}
This study addresses the inconsistency of contemporary literature on defining the link between leadership styles and personality traits. The plethora of literature on personality traits has culminated into symbolic big five personality dimensions but there is still a dearth of research on developing representative leadership styles despite the perennial fascination with the subject. Absence of an unequivocal model for developing representative styles in conjunction with the use of several non-mutually exclusive existing leadership styles has created a discrepancy in developing a coherent link between leadership and personality. This study sums up 39 different styles of leadership into five distinct representative styles on the basis of similar theoretical underpinnings and common characteristics to explore how each of these five representative leadership style relates to personality dimensions proposed by big five model.
\end{abstract}

Keywords Leadership Styles, Personality Traits, Big Five Model

\section{Introduction}

Leadership-personality literature has witnessed a new resurged attention (Johnson et al. [1]; Anderson [2]; De Hoogh et al. [3]). This is because, despite an end to the chapter of trait studies in determining the effectiveness of leaders in 1960's, divisiveness about whether leadership is an innate phenomenon or learned behavior has always remained a noteworthy debate in the anthology of leadership (e.g. Kirkpatrick and Locke [4]; Johnson et al. [1]; Rowley [5]; Ruvolo et al. [6]; Marques [7] ). This study endeavors to identify if symbolic personality trait variants proposed by big five personality framework can be linked with leadership, however, by using the representative leadership styles derived from the long list of styles presented in the contemporary literature on leadership.
Emergence of assorted leadership styles have expanded the literature and many researchers have endeavored to relate selected styles with big five personality model (e.g. Van Eeden et al. [8]; De Hoogh et al. [3]; Zopiatis and Constanti [9]; Judge and Bono [10]). However, how personality traits are related to leadership styles have given erratic results (Anderson [2]). The inconsistency on formulation of a definitive link between leadership styles and personality traits is due to the proliferation of overlapping leadership styles in the realm of leadership which have not been encapsulated into a logical arrangement with reference to common frame of reference. Linking the existing leadership styles with big five representative personality traits thus has given inconsistent results due to the absence of those leadership styles which can epitomize the several styles present in the leadership literature. Thus, instead of selecting one or two leadership styles and linking them to big five personality traits like previous studies, this study has amalgamated the much discussed existing leadership styles in five distinguished clusters each representing a distinct leadership style and analyzed how each style relates to the personality trait variants of the big five model.

The need to group the various leadership styles arises from the fact that the voluminous leadership literature lacks an unequivocal model for developing symbolic leadership styles. Dilemma of profuse leadership styles having overlapping areas is similar to what researchers of personality traits confronted in the beginning years when large number of personality traits were identified among which only few were found consistent in different cases. However, extensive research on personality has gradually and suitably culminated into symbolic personality traits as advanced by the big five model but the discussion on leadership remains scattered which makes it impossible to effectively link the discussion on leadership styles with personality dimensions. Hence, it is not only important but also necessary to organize the scattered list of leadership styles in logical sequence to identify mutually exclusive areas, streamline the discussion on this topic and to present a 
more practical configuration of leadership styles to be compared with other structured dimensions including the personality traits.

This research adds to the past literature by defining a new framework of leadership entailing representative leadership styles derived after an extensive literature review. This framework is much required to eliminate the mutual exclusiveness prevailing among the inordinate number of existing leadership styles as well as to create a coherent link with other structured frameworks including personality dimensions. Also, extant controversies in the literature about inconsistent results on linking personality with leadership styles are adequately addressed by logically tracing the root cause to overlapping leadership styles. This study also opens up a new consideration on the possible facet of leadership after organizing the leadership styles along main dimensions that are able to sketch the overview of leadership. Future researchers can use this framework to link leadership styles with other structures.

The remainder of the paper is organized into five additional sections. Section two, following the introduction part, discusses the important contributions of past literature on leadership and presents the list of leadership styles which are subsequently organized into a logical arrangement of five groups. Section three explains the literature review on linking leadership with the personality traits. Section four presents the empirical framework to test the model; linking five representative leadership styles with the big five personality dimensions. Section five and six highlight the results, discussion and conclusion of study. Implications of study are presented at the end.

\section{Leadership Defined}

Leadership has been an intriguing subject to sundry throughout the history as reflected by the plethora of literature on the subject available today (Muczyk and Reimann [11]; Gini [12]; De Vries[13]; Zopiatis and Constanti [9]). Although the term "leadership" was first coined in the first half of the nineteenth century (Bass \& Bass, [14]), human endeavors knowingly or discreetly have always abhorred a leadership void by crying out for it in order to be rescued or simply to be led (Gardner [15]). According to Bass \& Bass [14], leadership is a "widely discussed and popular topic" but when it comes to defining this much conferred concept, the literature has not shed light on a concerted definition or its constitution (Burns [16]; Jago [17]; Muczyk and Reimann [11]; Rost, quoted in Gini [12]) and moreover has produced almost as many definitions as the number of authors who penned down about it (Stogdill [18]). It was not, however, the incompetency or lack of research on the subject of leadership, by those who inscribed about it, but the different outlook adopted about what constitutes a leader, what does he do and how to become one if possible at all.

Yukl [19] defines leadership as "the process of influencing others to understand and agree about what needs to be done and how to do it, and the process of facilitating individual and collective efforts to accomplish shared objectives." Simplifying the definition, leadership is the ability to influence a group towards the achievement of goals.

\subsection{Leadership Styles}

A thorough literature search was conducted to identify the existing leadership styles and to derive a framework for systematically arranging those styles into representative groups. The leadership labyrinth under the realm of three main scientific paradigms i.e. Trait, Behavior and Contingency has extended to various styles. The constituent leadership styles of the three paradigms, frequently discussed and comparatively well-articulated in the literature, include autocratic, democratic, participative, directive, task-oriented, relations-oriented, transformational, transactional, charismatic, laissez-faire and servant leadership.

Autocratic leadership style, one of the primeval styles, is characterized by outright control over the followers with little or no concern for establishing relationship with them. Moreover, decision making resides chiefly with the leader who neither consults with the followers nor seeks their input in any matter. Autocratic leaders demand obedience and strict adherence to rules (Bass \& Bass [14]) and have been found to negatively impact group stability and effectiveness (Van Vugt et al. [20]). Thus, followers have taken to less fancy this style as they feel devoid of required motivational push from the leaders (De Cremer [21]). Democratic Leadership style is often placed at an antithetical end from autocratic leadership style on the leadership continuum. Democratic leaders engage in "group decision making, active member involvement, honest praise and criticism, and a degree of comradeship (Gastil [22]). Also, Foels et al. [23] found in their study that democratic leadership results in more satisfied group members as opposed to autocratic style because members prefer leaders who allow for input in decision making.

Involvement of subordinates in decision-making process is also the key defining feature of a participative leader who is considerate of his subordinates' opinions (Rok [24]). A participative leader seeks to share power and decision making with subordinates as well as tries to attain a consensus among them (Bass \& Bass, [14]). Moreover, according to Bass \& Bass [14] participative leader creates a conducive environment for his subordinates to engage in active participation to solve problems and make informed decisions while he, himself, remains "an active member among equals". Also, Huang et al. [25] found in their study that participative leadership creates feelings of empowerment and trust-in-supervisor for both managerial and non-managerial subordinates and there exists a strong association between participative leadership behavior and task performance of managerial subordinates. In contrast to participative leadership, directive style of leadership 
involves instructing and commanding the subordinates and assigning them goals in accordance with the leader's vision (Pearce and Sims Jr. [26]). Directive leadership style differs from participative in that participative leadership entails making a decision with subordinates whereas the former deals with delegating task to subordinates after a decision has been made (Muczyk and Reimann [11]). Bass \& Bass [14] have summarized three conditions for directive style to be effective namely: structure is required, the leader is equipped with necessary information and quality of the decision outweighs the commitment of the followers.

Care for clarification of goals and objectives is also advanced by task-oriented leadership which is additionally characterized by planning work-unit activities, organizing the task into steps, coordination and monitoring work-unit, informing subordinates about an evaluating criteria and resolving work-related problems (Tabernero et al. [27]; Yukl [28]). The celebrated theoretical base discussing task-oriented leader is Fiedler's contingency theory of leadership which proposes that task orientation should be exercised in either highly favorable/unfavorable situations or in situations under which the leader has extremely high/low control (Bass \& Bass [14]). Yukl [28] notes that a task-oriented leader has its prime focus on achieving optimal efficiency with organizational resources. Relations-Oriented leadership style, in stark contrast to task-oriented style of leadership, emphasizes on building leader-member relationship, supporting, developing, recognizing and empowering subordinates (Yukl [28]). Relations-oriented leaders have confidence in the team's ability and provide complete support to the subordinates to complete the task at hand (Tabernero et al. [27]). According to Fiedler's contingency theory, relations-orientation should be exercised when situation is moderately favorable to the leader or the leader has moderate control over situation (Bass $\&$ Bass [14]).

In congruence with autocratic, directive, task-oriented leadership, transactional leadership is a style which Van Eeden et al. [8] have defined as a social exchange process in which the leader delineates to the followers what needs to be done to successfully honor the transaction in order to receive reward or avoid punishment. Studied in it's more corrective and detailed form i.e. management by exception, transactional leaders exercise either active or passive management by exception. In the former, leaders specify standards of compliance and keep an active check for possible deviances and errors to take corrective actions before or when they occur (Bass et al. [29]; Van Eeden et al. [8]). In Passive management by exception, a leader does not intervene until the problem has occurred and then resorts to its solution (Eagly et al. [30]).

Enlarging the role of transactional leader, Bass [31] explained transformational leadership as a style which also focuses on followers' motivation, understanding, maturity and self-worth. Transformational leadership, delineated originally in 1980s, has been attributed as a major contribution in the anthology of leadership (Hunt [32]).
Burns [16] defines transforming leader as the one who raises the followers' level of consciousness, enables them to transcend their self-interest for the sake of the organization and increases the followers' level of need to higher level of achievement and self-actualization. Jung and Avolio [33] found in their study that transformational leadership has direct as well as indirect effects on followers' performance mediated through value congruence of leader and follower. Bernard Bass has expanded the full range leadership model (transactional and transformational) by including laissez-faire style of leadership (Van Eeden et al. [8]). Bass [31] termed laissez faire as non-leadership component which emerges when leaders are unavailable for assistance or discussion of critical junctures. Laissez-faire style reflects a failure on the part of the leader to take responsibility for managing (Eagly et al. [30]). Skogstad et al. [34] have studied the dark side of laissez-faire, labeling it as a destructive behavior instead of a zero type of leadership style, and concluded that this style is associated with stressful environment with high levels of role stress and interpersonal conflict.

The above traditional approaches to leadership have been contrasted by Yukl [35] with charismatic style of leadership by labeling it as a style that focuses on emotions and values rather than rational processes. Bass \& Bass [14] have deemed two main attributes to be essential for charismatic leadership style namely: leaders should be determined, self-confident, and emotionally expressive and on the other hand the followers must identify with their leaders in all situations. Along with transformational leadership, charismatic style has been attributed as the major contribution in transforming the leadership field (Hunt [32]). However, Yukl [35] has proposed a conceptual flaw in these two leadership theories due to extensively drawn analogies of their underlying concepts in recent literature, raising the doubt on the need of two separate styles.

A stark contrast to a conservatively held definition of leader, servant leadership style emerged to identify a leader as a servant instead of a hero. Postulated by Robert Greenleaf in modern era, servant leadership is devoid of self-interest and is primarily focused on followers (Stone et al. [36]). A servant leader strives to serve others first (Beazley and Gemmill [37]) by putting their interest at the forefront. Servant leaders function as stewards who are entrusted with the responsibility of the holistic development of their followers to help them achieve the level of self-fulfillment (Pekerti and Sendjaya [38]). Russell and Stone [39] in their theoretical study identified nine attributes namely: vision, honesty, integrity, trust, service, modeling, pioneering, appreciation of others and empowerment to be the effective characteristics of servant leadership.

The unabridged list of leadership styles inclusive of the above mentioned leadership styles along with the many others discussed in the literature are presented in Table 1 enlisting the characteristics of each style along with few references. 
Table 1. List of leadership styles and their key characteristics as presented in the past literature

\begin{tabular}{|c|c|c|c|}
\hline \multicolumn{2}{|r|}{ Leadership style } & \multirow{2}{*}{$\begin{array}{c}\text { Key Characteristics } \\
\begin{array}{c}\text { Punitive, less concerned for socio-emotional dimension of group, } \\
\text { dominating, dictatorial, unilateral decision making }\end{array}\end{array}$} & \multirow{2}{*}{$\begin{array}{l}\text { Referred by } \\
\text { Van Vugt et al. [20]; De Cremer [21]; } \\
\text { Foels et al. [23]; etc. }\end{array}$} \\
\hline 1. & Autocratic Leadership & & \\
\hline 2. & Democratic Leadership & $\begin{array}{l}\text { Considerate, participative, concerned with maintaining } \\
\text { relationships with others, group decision making }\end{array}$ & $\begin{array}{l}\text { Gastil [22]; Foels et al. [23]; Woods } \\
\text { [40] etc. }\end{array}$ \\
\hline 3. & Laissez-Faire Leadership & $\begin{array}{l}\text { Lack of involvement, avoidance of responsibilities, resistance in } \\
\text { discussing critical issues }\end{array}$ & $\begin{array}{l}\text { Eagly et al. [30] ; Bass [31] ; } \\
\text { Skogstad et al. [34] etc. }\end{array}$ \\
\hline 4. & Transactional Leadership & $\begin{array}{l}\text { Leader-Follower exchanges, clarification of subordinate } \\
\text { responsibilities, contingent rewards }\end{array}$ & $\begin{array}{l}\text { Van Eeden et al. [8]; Bass et al. [29]; } \\
\text { Eagly et al. } \quad[30] ; \text { etc. }\end{array}$ \\
\hline 5. & Task Oriented Leadership & $\begin{array}{l}\text { Planning and organizing work activities, clarification of roles, } \\
\text { resolving work-related problems, focus on goal achievement }\end{array}$ & $\begin{array}{l}\text { Tabernero et al. [27] ; Yukl [28]; } \\
\text { Eagly and Johnson [41] etc. }\end{array}$ \\
\hline 6. & Interpersonal Leadership & $\begin{array}{l}\text { Tactful, enthusiastic, encouraging, confidence builder, morale } \\
\text { booster, motive arouser, honest, sincere, trustworthy, extrovert }\end{array}$ & $\begin{array}{l}\text { Fleming [42]; Zander [43]; Brodbeck } \\
\text { et al. [44] etc. }\end{array}$ \\
\hline 7. & $\begin{array}{l}\text { Transformational } \\
\text { Leadership }\end{array}$ & $\begin{array}{l}\text { Vision, inspirational communication, intellectual stimulation, } \\
\text { influence, empowerment, high performance expectations }\end{array}$ & $\begin{array}{l}\text { Bass [31]; Jung and Avolio [33]; } \\
\text { Avolio et al. [46] etc. }\end{array}$ \\
\hline 8. & Charismatic Leadership & $\begin{array}{l}\text { Strategic vision, unconventional behavior, agents of change, } \\
\text { sensitive to the needs of followers, risk orientation, extrovert }\end{array}$ & $\begin{array}{l}\text { De Hoogh et al. [3]; Hunt [32]; Yukl } \\
\text { [35]; etc. }\end{array}$ \\
\hline 9. & Distributed Leadership & $\begin{array}{l}\text { Collaborative, intuitive working relations, institutionalized } \\
\text { practices }\end{array}$ & $\begin{array}{l}\text { Gronn [46]; Mehra et al. [47]; } \\
\text { Mayrowetz [48] etc. }\end{array}$ \\
\hline 10. & Participative Leadership & $\begin{array}{l}\text { Shared decision making, values others' input, seek consensus, } \\
\text { increased autonomy and empowerment to subordinates }\end{array}$ & $\begin{array}{l}\text { Bass and Bass [14]; Rok [24]; Huang } \\
\text { et al. [25] etc. }\end{array}$ \\
\hline 11. & Directive Leadership & $\begin{array}{l}\text { Issuing instructions and commands, assigning goals, providing } \\
\text { members with a framework for decision making }\end{array}$ & $\begin{array}{l}\text { Muczyk and Reimann [11]; Pearce and } \\
\text { Sims Jr. [26]; Kahai et al. [49] etc. }\end{array}$ \\
\hline 12. & Ethical Leadership & $\begin{array}{l}\text { Awareness for others, considerate, honest, altruistic, caring, } \\
\text { principled, internal locus of control, proactive, co-operative }\end{array}$ & $\begin{array}{l}\text { Walumbwa et al. [50]; Brown and } \\
\text { Trevińo [51]; Toor and Ofori [52] } \\
\text { etc. }\end{array}$ \\
\hline 13. & Authoritative Leadership & $\begin{array}{l}\text { Assertive, supportive, demanding, responsive, manipulative, } \\
\text { paternalistic }\end{array}$ & $\begin{array}{l}\text { Martin [53]; Dinham [54]; Pellegrini } \\
\text { and Scandura [55] etc. }\end{array}$ \\
\hline 14. & Authoritarian Leadership & $\begin{array}{l}\text { Self-oriented, rigid, defensive, apathetic, assertive, abusive, } \\
\text { exploitive, task-oriented, low responsiveness }\end{array}$ & $\begin{array}{l}\text { Martin [53];Pellegrini and Scandura } \\
\text { [55]; Kiazad, et al. [56] etc. }\end{array}$ \\
\hline 15. & Intellectual Leadership & $\begin{array}{l}\text { Clear vision, higher level of cognitive ability, conscientious, } \\
\text { proactive, free from fear, self-regulated, challenge status quo }\end{array}$ & $\begin{array}{l}\text { Dealtry [57]; Andreasen [58]; Versi } \\
\text { [59] etc. }\end{array}$ \\
\hline 16. & Instrumental Leadership & $\begin{array}{c}\text { Neurotic, require high commitment from followers, task and goal } \\
\text { oriented, functionalist approach }\end{array}$ & $\begin{array}{l}\text { Rossel [60]; Rees and Segal[61]; } \\
\text { Southwork [62] etc. }\end{array}$ \\
\hline 17. & Coercive Leadership & $\begin{array}{l}\text { Conformity, repressed creativity, aggressive, inflexible, use of } \\
\text { threat, self-centered, authoritarian, fear-driven }\end{array}$ & $\begin{array}{l}\text { Spector [63]; Goleman [64]; Skodvin } \\
\text { and Andresen [65] etc. }\end{array}$ \\
\hline 18. & Team-oriented Leadership & $\begin{array}{l}\text { Collaborative, team integrator, prefers status quo, encourage } \\
\text { diversity, democratic, supportive, conflict manager }\end{array}$ & $\begin{array}{l}\text { Kezar [66]; Javidan et al. [67]; Day et } \\
\text { al. [68] etc. }\end{array}$ \\
\hline 19. & Delegative Leadership & $\begin{array}{l}\text { Procedural fairness, low need for dominance, shared power, } \\
\text { motivate subordinates, seek consensus, maintains relationships }\end{array}$ & $\begin{array}{l}\text { Leana [69]; Kuhnert [70]; Krause et al. } \\
{[71] \text {; etc. }}\end{array}$ \\
\hline 20. & Autonomous Leadership & $\begin{array}{l}\text { Individualistic, encourage novelty, disrupts existing policies, } \\
\text { facilitates knowledge transfer, responsible for task accomplishment }\end{array}$ & $\begin{array}{l}\text { Elloy and Alan [72]; Taggar et al. [73]; } \\
\text { Patanakul et al. [74] etc. }\end{array}$ \\
\hline 21. & Coaching Leadership & $\begin{array}{l}\text { Facilitator, authentic, compassionate, candid, interpersonally } \\
\text { sensitive, develop people for future, motivating }\end{array}$ & $\begin{array}{l}\text { Hicks and McCracken [75]; Nyman } \\
\text { and Thach [76]; Robertson [77] etc. }\end{array}$ \\
\hline 22. & Affiliative Leadership & $\begin{array}{l}\text { Motivator in stressful time, creates harmony among team, } \\
\text { empathetic, conflict reducer, low on consultation, relationship } \\
\text { oriented, visionary }\end{array}$ & $\begin{array}{l}\text { Goleman [64]; Goleman et al. [78]; } \\
\text { Bennis [79] etc. }\end{array}$ \\
\hline 23. & Supportive Leadership & $\begin{array}{c}\text { Interpersonal trust, environment conducive to psychological } \\
\text { well-being of followers, employee empowerment, provides support } \\
\text { to followers, caring }\end{array}$ & $\begin{array}{l}\text { Rafferty and Griffin [80]; Muller et al. } \\
\text { [81]; Schyns et al. [82] etc. }\end{array}$ \\
\hline 24. & $\begin{array}{l}\text { Relationship-Oriented } \\
\text { Leadership }\end{array}$ & $\begin{array}{l}\text { Concern and respect for followers, express appreciation and } \\
\text { support, build friendly and supportive relationships }\end{array}$ & $\begin{array}{l}\text { Bass and Bass [14]; Tabernero et al. } \\
\text { [27]; Yukl [28] etc. }\end{array}$ \\
\hline 25. & $\begin{array}{l}\text { Consultative/Advisory } \\
\text { Leadership }\end{array}$ & $\begin{array}{l}\text { Provide professional guidance to followers, operate in less } \\
\text { ambiguous situation, low external and high internal locus control }\end{array}$ & $\begin{array}{l}\text { Krause et al. [71]; Yousef [83]; } \\
\text { Selart [84]; etc. }\end{array}$ \\
\hline 26. & $\begin{array}{l}\text { Humane-oriented } \\
\text { Leadership }\end{array}$ & $\begin{array}{l}\text { Fair, altruistic, compassionate, modest, strong labor representation, } \\
\text { social welfare, benevolent, motivational, interpersonal relationship }\end{array}$ & $\begin{array}{l}\text { Brodbeck et al. [85]; Winston and } \\
\text { Ryan [86]; Paris et al. [87] etc. }\end{array}$ \\
\hline
\end{tabular}




\begin{tabular}{|c|c|c|c|}
\hline 27. & Expressive Leadership & $\begin{array}{l}\text { Anti-authoritarian, interpersonally sensitive, grant autonomy, } \\
\text { relationship motivated leadership, socio-emotional }\end{array}$ & $\begin{array}{l}\text { Rossel [60]; Rees and Segal [61]; } \\
\text { Southwork [62] etc. }\end{array}$ \\
\hline 28. & Visionary Leadership & $\begin{array}{l}\text { Emotionally expressive, interpersonally sensitive, foresight, } \\
\text { proactive, inspirational, guides and empowers followers, changes } \\
\text { status quo }\end{array}$ & $\begin{array}{l}\text { Westley and Mintzberg [88]; Brown } \\
\text { and Anfara [89]; Groves [90]etc. }\end{array}$ \\
\hline 29. & Pacesetting Leadership & $\begin{array}{l}\text { Sets high standard and expects excellence from subordinates, } \\
\text { authoritative, high on conscientiousness }\end{array}$ & $\begin{array}{l}\text { Goleman [64]; Bennis [79]; Giritli and } \\
\text { Oraz [91] etc. }\end{array}$ \\
\hline 30. & Narcissist Leadership & $\begin{array}{l}\text { Self-centered, status conscious, conflict inducer, unsympathetic, } \\
\text { haughty, exploitive, seek attention, aggressive, unforgiving nature }\end{array}$ & $\begin{array}{l}\text { Rosenthal and Pittinsky [92]; Brunell } \\
\text { et al. [93]; Ouimet [94]; etc. }\end{array}$ \\
\hline 31. & E-leadership & $\begin{array}{l}\text { Swift, more towards autonomy, flexible in dynamic environment, } \\
\text { expertise in building and leading networks }\end{array}$ & $\begin{array}{l}\text { Avolio et al. [95]; Pulley and Sessa } \\
\text { [96]; Gurr [97] etc. }\end{array}$ \\
\hline 32. & $\begin{array}{l}\text { Achievement-Oriented } \\
\text { Leadership }\end{array}$ & $\begin{array}{l}\text { Maintain high level of performance, set challenging goals, strive for } \\
\text { excellence, show confidence in followers, high internal locus of } \\
\text { control }\end{array}$ & $\begin{array}{l}\text { Griffin [98]; Dragoni[99]; Muller and } \\
\text { Turner [100] etc. }\end{array}$ \\
\hline 33. & Authentic Leadership & $\begin{array}{l}\text { Morally courageous, pro-social behavior, reliable, honest, social } \\
\text { justice and equality, optimistic, self-disciplined, self-expressive }\end{array}$ & $\begin{array}{l}\text { Avolio and Gardner [101]; Cooper et } \\
\text { al. [102]); Hannah et al. [103] etc. }\end{array}$ \\
\hline 34. & Servant Leadership & $\begin{array}{l}\text { Steward, follower-centric, altruistic, commitment for growth of } \\
\text { people, strong spiritual values and beliefs }\end{array}$ & $\begin{array}{l}\text { Beazley and Gemmill [37]; Pekerti } \\
\text { and Sendjaya[38]; Russell and Stone } \\
\text { [39]; etc. }\end{array}$ \\
\hline 35. & Citizen Leadership & $\begin{array}{l}\text { Egalitarian, commitment for growth of people, bring constructive } \\
\text { change, democratic, inspirational, innovative, team oriented }\end{array}$ & $\begin{array}{l}\text { Perreault[104]; Langone } \quad[105] ; \\
\text { Booker [106] etc. }\end{array}$ \\
\hline 36. & Aversive Leadership & $\begin{array}{l}\text { Relies on coercive power, authoritarian, cynical, exploitive, engage } \\
\text { in intimidation and dispensing reprimands, aggressive }\end{array}$ & $\begin{array}{l}\text { Pearce and Sims Jr. [26]; Bligh et al. } \\
\text { [107]; Thoroughgood et al. [108] etc. }\end{array}$ \\
\hline 37. & Empowering Leadership & $\begin{array}{c}\text { Concerned with employee performance and satisfaction, grant } \\
\text { autonomy, share power, agreeable, team-oriented, encourage } \\
\text { self-development }\end{array}$ & $\begin{array}{l}\text { Pearce and Sims Jr. [26]; Sims Jr. et al. } \\
\text { [109]; Vecchio et al. [110]; Martin et } \\
\text { al. [111] etc. }\end{array}$ \\
\hline 38. & Opinion Leadership & $\begin{array}{l}\text { Dominant, persistent, social; confident, high degree of social } \\
\text { maturity innovativeness, withstand powerful social inhibitors }\end{array}$ & $\begin{array}{l}\text { Robertson and Myers [112]; Myers } \\
\text { and Robertson [113]; Chan and Misra } \\
{[114] \text { etc. }}\end{array}$ \\
\hline 39. & Self-Protective Leadership & $\begin{array}{l}\text { Status-conscious, self-centered, conflict-inducing, procedural and } \\
\text { face-saving }\end{array}$ & Javidan et al. [67] \\
\hline
\end{tabular}

\subsection{Representative Leadership Styles}

Thirty nine leadership styles which stemmed from scrutinizing the literature are placed in five distinct groups in order to develop an unequivocal model of symbolic leadership styles. The existing long list of styles makes it impossible to effectively link the discussion on leadership styles with other frame of reference such as personality dimensions. Therefore, it is essential to organize the scattered list of leadership styles in logical sequence. Such an effort can identify the overlapping as well as mutually exclusive areas to streamline the discussion on this topic. Thus, to fill this void in the past literature this study amalgamates the several leadership styles into limited number of representative styles based on their common characteristics to present a more practical configuration of leadership styles to be compared with other frame of reference.

Researchers of personality traits confronted with a similar challenge at first when they had to deal with exorbitant number of personality traits among which only few were found consistent in different cases. However, extensive research on personality has gradually and suitably culminated into symbolic personality traits proposed by the big five model. As a result, discussion on personality framework is well-structured around the five dimensions of big five model. On the other side, an imbricated list of leadership styles presents a challenge to be arranged along the representative dimensions. This study proposes an unequivocal model of representative leadership styles to enable the comparison of leadership styles with other structured dimensions including the personality traits.

The proposed assortment will also aid to eliminate the existing controversies in the past literature which is brimming with leadership styles, however, without catering to their mutual exclusiveness. Therefore, to bring more consistency in the leadership literature, this study has derived five representative styles which are non-mutually exclusive. Also, these representative styles have been developed utilizing a common frame of reference i.e. focus on leader and centralization of decision making. The leadership styles (LS1 to LS4) can be seen along a continuum of focus and centralized decision-making gradually shifting from leader to subordinates. LS5 is an exceptional case and is included due to its importance to understand a complete model of leadership.

The five groups are indicative of five distinct leadership styles whose characteristics are given in Table 2. The six critical areas have been selected to see the difference in five different styles. i. e. role of the leader, leader's concern for 
others, distance from followers, his decision making style, follower's motivation and leader's focus on followers' growth; as they all are essential components of the leadership pie. Based on these characteristics of representative leadership styles, an amalgamation of the 39 leadership styles identified in five distinct clusters are given in Table 3.

Table 2. Representative Leadership Styles

\begin{tabular}{|c|c|c|c|c|c|}
\hline & LS1 & LS2 & LS3 & LS4 & LS5 \\
\hline Role of Leader & $\begin{array}{c}\text { Clearly define } \\
\text { instructions and } \\
\text { performance standards }\end{array}$ & $\begin{array}{l}\text { Encourage } \\
\text { participation }\end{array}$ & $\begin{array}{c}\text { Seek highest } \\
\text { standards of } \\
\text { excellence }\end{array}$ & Assist followers & $\begin{array}{l}\text { Leave followers to } \\
\text { do task themselves }\end{array}$ \\
\hline $\begin{array}{l}\text { Leader's concern for } \\
\text { others } \\
\end{array}$ & Little & High & High & Very High & Little or None \\
\hline Distance from followers & High & Moderate & Low & Low & High \\
\hline $\begin{array}{l}\text { Leader's decision making } \\
\text { style }\end{array}$ & Unilateral & $\begin{array}{l}\text { Shared decision } \\
\text { making through } \\
\text { followers }\end{array}$ & $\begin{array}{l}\text { Shared decision } \\
\text { making by } \\
\text { persuasion }\end{array}$ & $\begin{array}{l}\text { Shared decision } \\
\text { making in the } \\
\text { interest of } \\
\text { followers } \\
\end{array}$ & $\begin{array}{l}\text { Minimal or no role in } \\
\text { decision making }\end{array}$ \\
\hline Followers' motivation & $\begin{array}{c}\text { Followers are incapable } \\
\text { of performing tasks } \\
\text { themselves and are } \\
\text { moderately motivated }\end{array}$ & $\begin{array}{c}\text { Followers are equal } \\
\text { with the leader and } \\
\text { are highly } \\
\text { motivated }\end{array}$ & $\begin{array}{c}\text { Followers identify } \\
\text { with the leaders } \\
\text { and are highly } \\
\text { motivated }\end{array}$ & $\begin{array}{l}\text { Followers try to } \\
\text { reach their level of } \\
\text { self-fulfillment }\end{array}$ & $\begin{array}{c}\text { Followers are } \\
\text { frustrated and } \\
\text { unmotivated }\end{array}$ \\
\hline $\begin{array}{l}\text { Focus on followers' } \\
\text { growth }\end{array}$ & $\begin{array}{l}\text { None as leader } \\
\text { emphasizes followers } \\
\text { only to follow } \\
\text { instructions }\end{array}$ & $\begin{array}{l}\text { Moderate as leader } \\
\text { provides training } \\
\text { and development to } \\
\text { the followers }\end{array}$ & $\begin{array}{l}\text { Moderately high as } \\
\text { leader focus on the } \\
\text { competence } \\
\text { development of } \\
\text { followers }\end{array}$ & $\begin{array}{l}\text { High as leader's } \\
\text { top priority is to } \\
\text { help others } \\
\text { achieve their goals }\end{array}$ & $\begin{array}{l}\text { None as leader } \\
\text { remains uninvolved }\end{array}$ \\
\hline
\end{tabular}

* LS1-LS5 indicates leadership styles 1-5

Table 3. Leadership styles clustered into five representative styles based on common characteristics

\begin{tabular}{|c|c|c|c|c|}
\hline LS1 & LS2 & LS3 & LS4 & LS5 \\
\hline Autocratic & Participative & Transformational & Servant & Laissez-faire \\
\hline Transactional & Interpersonal & Visionary & Citizen & \\
\hline Task-oriented & Coaching & Charismatic & Authentic & \\
\hline Directive & Affiliative & Achievement-oriented & Humane-oriented & \\
\hline Authoritarian & Supportive & Pacesetting & Ethical & \\
\hline Aversive & Relations-oriented & Empowering & & \\
\hline Narcissist & Authoritative & E-leadership & & \\
\hline Instrumental & Consultative-advisory & Distributed & & \\
\hline Coercive & Democratic & Intellectual & & \\
\hline \multirow[t]{3}{*}{ Self-protective } & Expressive & Opinion & & \\
\hline & Team-oriented & Autonomous & & \\
\hline & Delegative & & & \\
\hline
\end{tabular}

\footnotetext{
* LS1-LS5 indicates leadership styles 1-5
} 


\section{Leadership and Personality}

Do leaders emerge due to their personality? What traits predict the emergence of leaders in a group, their advancement to higher levels and their effective performance? Is it important to remember that some traits relevant to one criterion are relevant not for the other? Many classical and contemporary research studies have given answers to these questions differently and have discussed the relativity of personality traits with leadership styles (Kirkpatrick and Locke [4]; Anderson [2] etc.). One of the earliest approaches to understanding leadership was the trait approach emphasizing on the personality of leaders. Underlying this approach was the assumption that some people are born leaders endowed with certain personality traits, not possessed by others.

From 1900 till 1950 extensive research was conducted on the relationship of genetic makeup with leadership success. From 1904 to 1948, R. M. Stogdill reviewed 124 trait studies and examined trait approach and uncovered many traits that appeared consistent with leadership effectiveness like dependability, sociability, intelligence, initiative, persistence, self-confidence, consciousness, integrity, cooperativeness and adaptability showed a positive correlation between (Yukl [19]). However, Stogdill's review did not shed light on the basic premise of the trait approach that a person must possess a particular set of traits to become a successful leader. His studies showed that importance of particular trait is often relative to the situation (Anderson [2]). In 1974, Stogdill reviewed 163 more trait studies but he maintained that there is still no evidence for universal leadership traits and their relationship with the effectiveness of leadership (Yukl [19]).

An extensive research program was also conducted by McClelland and his associates from 1953 to 1985. The studies were around three social needs of a person: power, achievement and affiliation. A person with high need of power finds satisfaction in exercising influence over emotions, attitudes and behavior of others. Those who are 'socialized power oriented' are confident and have self-control, while those who 'personalized power oriented' are selfish and dominating (Boyatzis et al. [113]). On the other hand, a person who is achievement oriented gains satisfaction through accomplishment of difficult tasks and attaining standards of excellence by developing a better way of doing things and person with strong need for affiliation is usually sensitive to rejection and hostility and always seeks acceptance by society (Winter [114]). Thus, McClelland and his associates concluded that leadership effectiveness in large organization is related to high need for socialized power and need for achievement and low need for affiliation.

In 1983, M. M. Lombardo and M.W. McCall noticed that managers who had deep technical expertise at middle management lacked strategic aptitude when they were promoted to executive level, thus they got derailed. They conducted research at Center for Creative Leadership and interviewed 21 derailed managers and found differences between personality traits and leader behavior of successful managers and the sample of derailed managers. The reason interpreted for derailment of sample managers was that overdoing one leadership behavior is effective at one level and can become ineffective at other (McCall and Lombardo [115]; Kaiser and Hogan[116]). In the last decade of the millennium, Bernard Bass found that leaders with moderately high achievement motivation are more effective than those with low or high achievement motivation (Yukl, [19]).

Turning to contemporary researches from 2000 to 2006, Timothy A. Judge, Joyce E. Bono, Remus Ilies and Megan W. Gerhardt are the prominent names who analyzed trait perspective of leadership and used five-factor model for examining predictors of leadership and the effect on leadership styles. The results given by the meta-analysis of their research study showed the importance of five personality traits to determine the leadership style $(\mathrm{Ng}$ Kok-Yee et al. [117]; Judge et al. [118]).

\subsection{Personality Assessment and Big five model}

During the era of classical research studies of leadership and personality, there was no taxonomic model for personality assessment to develop and test theories. In 1934, L. L. Thurstone pioneered measurement of personality by providing raters with 60 trait adjectives to rate adjectives they might use to describe someone they knew well. He found five common factors that emerged in the account of inter-correlation of trait adjectives (Wiggins and Trapnell [119]; Burns [16]). Following Thurstone, Gordon Allport in 1936 categorized the vast number of traits in major categories (John et al. [120]).

In 1943, Cattel entered the field following the work by Allport and published his findings on personality assessment model of $16 \mathrm{PF}$ in 1950. According to him, human personality consists of 16 major traits of personality. In 1947, Eysenck's scale for personality measurement was introduced and became popular (Digman [121-122]). In the same decade J. P. Guilford also attempted to study, understand and test the trait approaches developed by early researchers and gave major reviews of his structural research programs and presented Guilford-Zimmerman Temperament Survey (GZTS), an approach to measure 10 traits personality (Rushton and Irwing [123]).

In 1961 Ernest C. Tupes and R. E. Christal investigated the factor model of traits by rating peers on 20 trait adjectives and generalized the five-factor model of personality having broad constructs of surgency, conscientiousness, agreeableness, neuroticism and culture (John et al. [120]; Wiggins and Trapnell [119]; Judge and Bono [10]). Continuing with the history of five-factor model, John Digman (1963-1986) is the famous name among many researchers for the long standing interest in this regard. Digman's early studies suggested that small number of factors can sufficiently explain personality as a whole and his further analyses show that these factors were around the dimensions of five-factor model (Wiggins and Trapnell 
[119]).

The proliferation of personality traits identified over the period of five decades had resulted in efforts to define personality traits in broad categories that could better help in research studies and in development of personality theories. The one such promising effort was also referred to creation of Big-Five model which gained popularity in 1980s and has rich history of academic credibility as it was widely used in the time of extensive research on personality in organizational context (Houghton et al. [124]). Also in recent years the researchers and leadership scholars have showed increasing interest in using this framework to facilitate interpretation of results in massive and confusing literature of leadership traits. Many, if not all, scholars believe that the domain of personality is a composite of five meta-constructs that contain all relevant traits (Crant and Bateman [125]).

The personality dimensions put forth by the Big Five model are extraversion, agreeableness, conscientiousness, emotional stability and openness to experience. Extraversion is characterized by traits like sociability, assertiveness, gregariousness and activeness. Extravert people are talkative, expressive and interactive and are more engaged in inspirational and personal appeal. On the other hand, people who are low on this dimension are introverts, who remain dethatched from people and avoid taking responsibilities (Cable and Judge [126]). The trait of agreeableness includes people who are warm-natured, trust worthy, cooperative, compliant, compassionate, and supportive. It is a state where the leader's trustworthiness is the most important factor among the subordinates (Sorenson et al. [127]). Conscientiousness encompasses dependability, responsibility, achievement orientation and deliberation. It entails following established rules and includes people who are persistent and organized (Perrewé and Spector, [128]; Judge et al., [118]; De Hoogh et al., [3]). Emotional Stability is the dimension opposite to neuroticism and people high on this trait are calm, self-confident, and secure whereas neurotic people are anxious, depressed, fearful, and lack self-confidence and self-esteem. The leaders who incline towards changing the status quo require high emotional stability (Judge and Bono, [10]). The last dimension is openness to experience which includes people who are imaginative, thoughtful, curious, perceptive and creative. People high on this dimension are non-conformists, unconventional, accept challenges and bear risk. These people are learning-oriented and show more readiness and openness to training (Barrick \& Mount, [125]).

\section{Empirical Framework}

This research has a twofold structure; one is the theoretical base for which extensive literature was explored to identify published studies of personality-leadership. An electronic search was conducted to find different leadership styles for the purpose of grouping them into a logical categorization which will eliminate their mutual exclusiveness. The theoretical ground has been augmented with an empirical perspective in order to deduce the relationship of representative leadership styles with personality traits.

Participants of the research include department heads/managers and their subordinates which for the purpose of this study are assumed as leaders and followers respectively. The scope of the research covers thirty-five organizations belonging to different industries such as software, banking, pharmaceutical, education and construction and on average each had 50 employees in total. From each organization one manager (mostly the topmost in the hierarchy/ or owner) with at least ten employees working directly under him/her was selected to measure personality. On the other hand, of the total number of subordinates of a manager, ten were randomly selected to rate the leadership style of their manager. Thus, the total sample included 35 managers or leaders and 350 subordinates.

The leaders were surveyed directly to identify their personality type but their leadership style was assessed indirectly by surveying the subordinates. This indirect interrogation was done to eliminate any chances of biasness and to introduce more accuracy in determining the leadership-personality link. Survey with leaders from industry and their respective ten subordinates marked the beginning of the data collection. Two questionnaires were designed in order to measure perceived leadership style and personality traits of the leaders.

\subsection{Assessment of Leadership Style}

A separate questionnaire for the subordinates was prepared and given to ten subordinates from each organization to rate their respective leader's leadership style on a 5-point response scale ranging from 1 (Strongly disagree) to 5 (Strongly agree). The five broad categories of leadership styles, from LS1 to LS5, were measured for each leader by presenting 5 statements for each broad category to the subordinates to represent their strength of agreeableness and disagreeableness against each statement. The questionnaire included twenty-five questions in total where items 1-5 measured LS1 which reflect giving clear instructions, setting performance standards and use of unilateral decision making; 6-10 measured LS2 which reflect seeking subordinates' input, encouraging participation and focus on building relationships; 11-15 measured LS3 which reflect having strong vision, encouraging subordinates to achieve challenging goals and explaining to them the outcome of their efforts; 16-20 measured LS4 which reflect prioritizing subordinates' interest and their personal development and helping them to achieve their goals and the rest measured LS5 which reflect little concern for subordinates, leave them to make decisions and to solve problems. The total twenty-five statements were rated by the subordinates to assess what they perceived to be their leader's style of leadership.

\subsection{Personality Assessment of Leader}

The leaders were surveyed to assess their personality type. The questionnaire for the leaders was adapted from the 
standard big five personality assessment questionnaire. The Big Five personality traits of leaders were measured with six statements; some worded positively while others negatively for each of five-factor construct of extraversion, conscientiousness, agreeableness, emotional Stability and openness to experience. Total thirty statements were presented to leaders to represent their strength of agreeableness and disagreeableness against each statement on a 5-point response scale ranging from 1 (Strongly disagree) to 5 (strongly agree). The first six items on the questionnaire inquired about extraversion, followed by conscientiousness, agreeableness, emotional stability and openness to experience.

\section{Results and Discussion}

The subordinates were surveyed to identify what they deemed to be the dominant leadership style of their respective leaders. Ten subordinates from each organization who were directly reporting to a particular leader completed the questionnaire. To identify the dominant leadership style of a leader, the responses of the subordinates were averaged out. High score on a leadership style is considered as the dominant leadership style of a leader whilst the lowest score represents that leader least has that leadership style. Table 4 indicates the responses of the subordinates for their respective leaders for all leadership styles. The data is arranged according to the highest score in a specific leadership style from LS1 to LS5. Highlighted figures show the highest scores among the five comparative leadership styles for each leader in the sample. Seven leaders score high on LS1, eight on LS2, eleven on LS3, five on LS4 and four on LS5.

However, further analysis was conducted to increase the reliability of using the highest average rating as the dominant style of the leaders by running one way anova for comparison of means and post-hoc tests.

Table 4. Average rating of leaders assigned to them by their subordinates on all five representative leadership styles

\begin{tabular}{|c|c|c|c|c|c|}
\hline & LS1 & LS2 & LS3 & LS4 & LS5 \\
\hline Leader 17 & 4.40 & 1.28 & 2.26 & 1.34 & 3.30 \\
\hline Leader 18 & 4.62 & 1.30 & 2.14 & 1.32 & 3.46 \\
\hline Leader 19 & 3.60 & 2.58 & 2.60 & 2.42 & 2.16 \\
\hline Leader 23 & 3.92 & 2.82 & 2.86 & 2.52 & 2.48 \\
\hline Leader 28 & 3.86 & 2.82 & 2.88 & 2.42 & 1.90 \\
\hline Leader 30 & 3.90 & 2.90 & 2.92 & 2.62 & 2.04 \\
\hline Leader 8 & 3.56 & 3.90 & 3.58 & 3.72 & 2.80 \\
\hline Leader 13 & 3.78 & 3.84 & 3.64 & 3.58 & 2.72 \\
\hline Leader 14 & 3.50 & 3.94 & 3.86 & 3.68 & 2.80 \\
\hline Leader 20 & 2.46 & 3.78 & 3.46 & 3.04 & 2.28 \\
\hline Leader 24 & 2.20 & 3.92 & 3.30 & 3.08 & 1.76 \\
\hline Leader 27 & 2.30 & 3.92 & 3.84 & 2.94 & 1.4 \\
\hline Leader 31 & 2.38 & 3.94 & 3.38 & 2.72 & 1.38 \\
\hline Leader 1 & 3.04 & 3.82 & 4.04 & 3.68 & 2.28 \\
\hline Leader 2 & 3.50 & 3.76 & 4.30 & 3.80 & 1.82 \\
\hline Leader 3 & 3.58 & 3.78 & 4.34 & 3.74 & 2.12 \\
\hline Leader 4 & 3.30 & 3.82 & 4.00 & 3.58 & 2.04 \\
\hline Leader 5 & 3.30 & 3.86 & 4.24 & 3.84 & 2.78 \\
\hline Leader 6 & 3.14 & 3.30 & 3.42 & 3.18 & 2.92 \\
\hline Leader 7 & 3.00 & 3.72 & 3.84 & 3.56 & 2.64 \\
\hline Leader 9 & 3.18 & 3.68 & 4.04 & 3.96 & 1.98 \\
\hline Leader 11 & 3.70 & 4.16 & 4.28 & 4.08 & 2.04 \\
\hline Leader 12 & 3.20 & 3.76 & 4.08 & 3.80 & 3.14 \\
\hline Leader 15 & 3.64 & 3.92 & 4.22 & 3.68 & 3.04 \\
\hline Leader 16 & 3.92 & 4.64 & 4.66 & 4.78 & 2.28 \\
\hline Leader 21 & 2.36 & 3.38 & 3.24 & 4.14 & 1.46 \\
\hline Leader 33 & 2.60 & 3.34 & 3.06 & 4.26 & 1.52 \\
\hline Leader 10 & 2.60 & 2.56 & 2.36 & 2.40 & 2.88 \\
\hline Leader 22 & 2.92 & 2.58 & 2.60 & 2.50 & 4.02 \\
\hline Leader 34 & 3.00 & 2.58 & 2.66 & 2.56 & 3.22 \\
\hline Leader 35 & 3.04 & 2.62 & 2.54 & 2.46 & 3.46 \\
\hline
\end{tabular}

* LS1-LS5 indicates leadership styles 1-5

**In each of the 35 cases, ten subordinates were presented with 25 questions, 5 each for one leadership style, to rate their leader on the 5 representative leadership styles. The scores of all ten subordinates were averaged out and the highest average score on a leadership style is assumed as the dominant leadership style of the particular leader. 


\subsection{One Way Anova and Post Hoc Analysis}

One-way anova test for comparison of means was run to maintain that the difference in means of five leadership styles is significant and hence one style with highest mean value is the dominant leadership style. The results of one-way Anova for each of the eighteen cases are presented in Table 5.

Table 5. One-way Anova for comparison of means

\begin{tabular}{|c|c|c|c|c|c|c|}
\hline Leader & Source & SS & $\mathrm{df}$ & MS & $\mathrm{F}$ & Prob $>F$ \\
\hline \multirow{2}{*}{1} & Between Groups & 511.12 & 4 & 127.78 & 20.77 & 0.000 \\
\hline & Within Groups & 276.90 & 45 & 6.15 & & \\
\hline \multirow{2}{*}{2} & Between Groups & 899.88 & 4 & 224.97 & 23.68 & 0.000 \\
\hline & Within Groups & 427.50 & 45 & 9.50 & & \\
\hline \multirow{2}{*}{3} & Between Groups & 687.92 & 4 & 171.98 & 29.72 & 0.000 \\
\hline & Within Groups & 260.40 & 45 & 5.79 & & \\
\hline \multirow{2}{*}{4} & Between Groups & 603.72 & 4 & 150.93 & 28.79 & 0.000 \\
\hline & Within Groups & 235.90 & 45 & 5.24 & & \\
\hline \multirow{2}{*}{5} & Between Groups & 324.28 & 4 & 81.07 & 5.93 & 0.001 \\
\hline & Within Groups & 614.70 & 45 & 13.66 & & \\
\hline \multirow{2}{*}{6} & Between Groups & 35.12 & 4 & 8.78 & 1.03 & 0.401 \\
\hline & Within Groups & 382.80 & 45 & 8.51 & & \\
\hline \multirow{2}{*}{7} & Between Groups & 261.92 & 4 & 65.48 & 5.93 & 0.001 \\
\hline & Within Groups & 497.20 & 45 & 11.05 & & \\
\hline \multirow{2}{*}{8} & Between Groups & 176.92 & 4 & 44.23 & 5.30 & 0.001 \\
\hline & Within Groups & 375.40 & 45 & 8.34 & & \\
\hline \multirow{2}{*}{9} & Between Groups & 715.32 & 4 & 178.83 & 10.25 & 0.000 \\
\hline & Within Groups & 785.40 & 45 & 17.45 & & \\
\hline \multirow{2}{*}{10} & Between Groups & 42.40 & 4 & 10.60 & 0.89 & 0.475 \\
\hline & Within Groups & 533.60 & 45 & 11.86 & & \\
\hline \multirow{2}{*}{11} & Between Groups & 859.12 & 4 & 214.78 & 31.74 & 0.000 \\
\hline & Within Groups & 304.50 & 45 & 6.76 & & \\
\hline \multirow{2}{*}{12} & Between Groups & 166.88 & 4 & 41.72 & 5.94 & 0.000 \\
\hline & Within Groups & 316.10 & 45 & 7.02 & & \\
\hline \multirow{2}{*}{13} & Between Groups & 206.92 & 4 & 51.73 & 10.42 & 0.000 \\
\hline & Within Groups & 223.40 & 45 & 4.96 & & \\
\hline \multirow{2}{*}{14} & Between Groups & 207.48 & 4 & 51.87 & 3.03 & 0.027 \\
\hline & Within Groups & 771.10 & 45 & 17.14 & & \\
\hline \multirow{2}{*}{15} & Between Groups & 189.60 & 4 & 47.40 & 18.25 & 0.000 \\
\hline & Within Groups & 116.90 & 45 & 2.59 & & \\
\hline \multirow{2}{*}{16} & Between Groups & 1100.68 & 4 & 275.17 & 141.68 & 0.000 \\
\hline & Within Groups & 87.40 & 45 & 1.94 & & \\
\hline \multirow{2}{*}{17} & Between Groups & 1785.08 & 4 & 446.27 & 64.14 & 0.000 \\
\hline & Within Groups & 313.10 & 45 & 6.96 & & \\
\hline \multirow{2}{*}{18} & Between Groups & 2088.72 & 4 & 522.18 & 61.19 & 0.000 \\
\hline & Within Groups & 384.00 & 45 & 8.53 & & \\
\hline \multirow[t]{2}{*}{19} & Between Groups & 300.12 & 4 & 75.03 & 17.10 & 0.000 \\
\hline & Within Groups & 197.40 & 45 & 4.38 & & \\
\hline
\end{tabular}




\begin{tabular}{|c|c|c|c|c|c|c|}
\hline 20 & Between Groups & 407.88 & 4 & 101.97 & 17.05 & 0.000 \\
\hline & Within Groups & 269.10 & 45 & 5.98 & & \\
\hline \multirow[t]{2}{*}{21} & Between Groups & 1061.88 & 4 & 265.47 & 64.12 & 0.000 \\
\hline & Within Groups & 186.30 & 45 & 4.14 & & \\
\hline \multirow[t]{2}{*}{22} & Between Groups & 401.68 & 4 & 100.42 & 27.69 & 0.000 \\
\hline & Within Groups & 163.20 & 45 & 3.62 & & \\
\hline \multirow[t]{2}{*}{23} & Between Groups & 341.80 & 4 & 85.45 & 25.60 & 0.000 \\
\hline & Within Groups & 150.20 & 45 & 3.33 & & \\
\hline \multirow[t]{2}{*}{24} & Between Groups & 752.72 & 4 & 188.18 & 22.00 & 0.000 \\
\hline & Within Groups & 384.90 & 45 & 8.55 & & \\
\hline \multirow[t]{2}{*}{25} & Between Groups & 933.88 & 4 & 233.47 & 55.94 & 0.000 \\
\hline & Within Groups & 187.80 & 45 & 4.17 & & \\
\hline \multirow[t]{2}{*}{26} & Between Groups & 1220.40 & 4 & 305.10 & 67.43 & 0.000 \\
\hline & Within Groups & 203.60 & 45 & 4.52 & & \\
\hline \multirow[t]{2}{*}{27} & Between Groups & 967.08 & 4 & 241.77 & 38.05 & 0.000 \\
\hline & Within Groups & 285.90 & 45 & 6.35 & & \\
\hline \multirow[t]{2}{*}{28} & Between Groups & 520.48 & 4 & 130.12 & 25.15 & 0.000 \\
\hline & Within Groups & 232.80 & 45 & 5.17 & & \\
\hline \multirow[t]{2}{*}{29} & Between Groups & 931.72 & 4 & 232.93 & 44.36 & 0.000 \\
\hline & Within Groups & 236.30 & 45 & 5.25 & & \\
\hline \multirow[t]{2}{*}{30} & Between Groups & 453.88 & 4 & 113.47 & 23.01 & 0.000 \\
\hline & Within Groups & 221.90 & 45 & 4.93 & & \\
\hline \multirow[t]{2}{*}{31} & Between Groups & 956.80 & 4 & 239.20 & 46.96 & 0.000 \\
\hline & Within Groups & 229.20 & 45 & 5.09 & & \\
\hline \multirow[t]{2}{*}{32} & Between Groups & 576.32 & 4 & 144.08 & 58.68 & 0.000 \\
\hline & Within Groups & 110.50 & 45 & 2.45 & & \\
\hline \multirow[t]{2}{*}{33} & Between Groups & 1011.88 & 4 & 252.97 & 71.73 & 0.000 \\
\hline & Within Groups & 158.70 & 45 & 3.52 & & \\
\hline \multirow[t]{2}{*}{34} & Between Groups & 85.48 & 4 & 21.37 & 5.42 & 0.001 \\
\hline & Within Groups & 177.50 & 45 & 3.94 & & \\
\hline \multirow[t]{2}{*}{35} & Between Groups & 176.48 & 4 & 44.12 & 13.34 & 0.000 \\
\hline & Within Groups & 148.80 & 45 & 3.30 & & \\
\hline
\end{tabular}

*Assuming $\alpha=0.05$, the results for each case are significant if $\mathrm{P}$ value is $<\alpha$

** Between groups effects are due to experiment whereas the within group effects indicate an unsystematic variation in the data

Since the $\mathrm{P}$ value is $<\alpha=0.05$ for all leaders except in the case of leader 6 and 10, $\mathrm{H} 1$ is accepted i.e. at least one of the five leadership styles is different from the other four and the difference in means is significant at $\alpha=5 \%$. Rejection of null hypothesis leads to acceptance of $\mathrm{H} 1$ and thus post-hoc test can be conducted to determine the dominant leadership style. Acceptance of null hypothesis in case of leader 6 and 10 leads to rejection of $\mathrm{H} 1$ and thus post-hoc test cannot be conducted to determine which leadership style is dominant.
Post-Hoc Analysis follows one-way anova analysis for comparing means only when the null hypothesis i.e. all the means are same and the perceived difference among them is meaningless is rejected. This analysis allows for identifying which means are different as well as the size of the difference. The highest difference will indicate the style with highest mean and thus will represent the dominant leadership style. The output of post-hoc analysis for all leaders except 6 and 10 are given in Table 6. 
Table 6. Post-hoc analysis

\begin{tabular}{|c|c|c|c|c|c|}
\hline Leader & Leader Style & Contrast & Std. Err. & $\mathrm{t}$ & Prob $>|t|$ \\
\hline 1 & 3 vs 5 & 8.80 & 1.11 & 7.93 & 0.000 \\
\hline 2 & 3 vs 5 & 12.40 & 1.38 & 9.00 & 0.000 \\
\hline 3 & 3 vs 5 & 11.10 & 1.06 & 10.32 & 0.000 \\
\hline 4 & 3 vs 5 & 9.80 & 1.02 & 9.57 & 0.000 \\
\hline 5 & 3 vs 5 & 7.30 & 1.65 & 4.42 & 0.001 \\
\hline 7 & 3 vs 5 & 6.00 & 1.49 & 4.04 & 0.002 \\
\hline 8 & 2 vs 5 & 5.50 & 1.29 & 4.26 & 0.001 \\
\hline 9 & 3 vs 5 & 10.30 & 1.87 & 5.51 & 0.000 \\
\hline 11 & 3 vs 5 & 11.20 & 1.16 & 9.63 & 0.000 \\
\hline 12 & 3 vs 5 & 4.70 & 1.19 & 3.97 & 0.027 \\
\hline 13 & 2 vs 5 & 5.60 & 0.99 & 5.62 & 0.000 \\
\hline 14 & 2 vs 5 & 5.70 & 1.85 & 3.08 & 0.028 \\
\hline 15 & 3 vs 5 & 5.90 & 0.72 & 8.19 & 0.000 \\
\hline 16 & 4 vs 5 & 12.50 & 0.62 & 20.06 & 0.000 \\
\hline 17 & 2 vs 1 & -15.60 & 1.18 & -13.22 & 0.000 \\
\hline 18 & 2 vs 1 & -16.60 & 1.31 & -12.71 & 0.000 \\
\hline 19 & 5 vs 1 & -7.20 & 0.93 & -7.69 & 0.000 \\
\hline 20 & 5 vs 2 & -7.50 & 1.09 & -6.86 & 0.000 \\
\hline 21 & 5 vs 4 & -13.40 & 0.90 & -14.73 & 0.000 \\
\hline 22 & 5 vs 4 & 7.60 & 0.85 & 8.92 & 0.000 \\
\hline 23 & 5 vs 1 & -7.20 & 0.81 & -8.81 & 0.000 \\
\hline 24 & 5 vs 2 & -10.80 & 1.30 & -8.26 & 0.000 \\
\hline 25 & 5 vs 4 & -12.10 & 0.91 & -13.24 & 0.000 \\
\hline 26 & 5 vs 4 & -14.10 & 0.95 & -14.82 & 0.000 \\
\hline 27 & 5 vs 2 & -12.60 & 1.12 & -11.18 & 0.000 \\
\hline 28 & 5 vs 1 & -9.80 & 1.01 & -9.63 & 0.000 \\
\hline 29 & 5 vs 2 & -12.20 & 1.02 & -11.90 & 0.000 \\
\hline 30 & 5 vs 1 & -9.30 & 0.99 & -9.36 & 0.000 \\
\hline 31 & 5 vs 2 & -12.80 & 1.00 & -12.68 & 0.000 \\
\hline 32 & 5 vs 1 & -10.20 & 0.70 & -14.55 & 0.000 \\
\hline 33 & 5 vs 4 & -13.70 & 0.83 & -16.31 & 0.000 \\
\hline 34 & 5 vs 4 & 3.30 & 0.88 & 3.72 & 0.005 \\
\hline 35 & 5 vs 4 & 5.00 & 0.81 & 6.15 & 0.000 \\
\hline
\end{tabular}

*Assuming $\alpha=0.05$, the results for each case are significant if $P$ value is $<\alpha$

** The contrast indicates that difference between the two styles in each case is the highest as compared to other possible comparisons with other styles.

The result indicates that the given the highest difference with a $p$ value less than $\alpha=0.05$, it can be maintained that due to the significant difference of means the highest mean is indeed representative of the dominant leadership style of leaders. Based on the post-hoc analysis of 33 cases, dominant leadership style has been determined for each of leader. However, the results for Leader 6 and 10 are not significant and in these cases subordinates are unable to differentiate clearly between the leadership styles of their respective leaders. Thus, these two cases are an exception to existing outcomes of the dominant leadership styles of the leaders. The results indicate that out of 35 cases, LS1 is the dominant style of leaders $17,18,19,23,28,30$ and 32 ; LS2 is the dominant style of leaders $8,13,14,20,24,27,29$ and 31 ; LS3 is the dominant leadership style of leaders $1,2,3,4$, $5,6,7,9,11,12$ and 15; LS4 is the dominant style of leaders
$16,21,25,26$ and 33 ; and LS5 is the dominant style of leader $10,22,34$ and 35 .

The data was collected also from leaders to assess their personality type by using the big five personality framework. The questionnaire given to leaders entailed 30 statements, six each for the five-factor constructs of the model. However, out of these six statements three were positively worded and the other three negatively. To take this into account, data for negatively worded statements was reverse coded and big five personality scores for each leader were computed. Highest score on a personality construct is considered as the dominant personality trait of a leader whilst the lowest score represents that leader least has that personality type. The big five personality scores of leaders are given in Table 7 followed by descriptive statistics for the five personality constructs in Table 8 
Table 7. Big five personality scores of leaders in the sample*

\begin{tabular}{|c|c|c|c|c|c|c|}
\hline Leadership style & Leader & Extraversion & Conscientiousness & Agreeableness & Emotional Stability & Openness to Experience \\
\hline 1 & 17 & 3.33 & 4.67 & 3.50 & 3.00 & 2.33 \\
\hline 1 & 18 & 3.50 & 4.83 & 3.50 & 2.67 & 2.33 \\
\hline 1 & 19 & 3.00 & 4.50 & 3.00 & 2.83 & 2.00 \\
\hline 1 & 23 & 3.60 & 4.67 & 2.33 & 3.00 & 2.50 \\
\hline 1 & 28 & 2.67 & 3.83 & 3.33 & 2.67 & 2.50 \\
\hline 1 & 30 & 2.83 & 4.00 & 2.67 & 2.33 & 2.33 \\
\hline 1 & 32 & 3.00 & 4.83 & 2.50 & 3.00 & 2.30 \\
\hline 2 & 8 & 3.83 & 3.67 & 4.00 & 3.83 & 3.67 \\
\hline 2 & 13 & 3.67 & 2.83 & 4.17 & 3.00 & 3.00 \\
\hline 2 & 14 & 3.17 & 3.67 & 3.83 & 3.00 & 3.33 \\
\hline 2 & 20 & 3.00 & 4.16 & 2.83 & 2.83 & 3.33 \\
\hline 2 & 24 & 2.83 & 3.33 & 3.00 & 3.17 & 2.83 \\
\hline 2 & 27 & 2.67 & 4.83 & 4.16 & 2.83 & 3.33 \\
\hline 2 & 29 & 3.33 & 2.30 & 2.67 & 3.50 & 3.33 \\
\hline 2 & 31 & 3.00 & 2.67 & 2.50 & 3.00 & 3.50 \\
\hline 3 & 1 & 3.83 & 4.67 & 3.83 & 3.67 & 3.00 \\
\hline 3 & 2 & 3.50 & 4.50 & 4.00 & 3.83 & 3.83 \\
\hline 3 & 3 & 3.00 & 5.00 & 4.00 & 2.83 & 4.00 \\
\hline 3 & 4 & 2.67 & 4.30 & 4.00 & 3.67 & 3.17 \\
\hline 3 & 5 & 2.83 & 2.33 & 3.17 & 3.67 & 3.33 \\
\hline 3 & 6 & 3.50 & 3.83 & 3.00 & 3.50 & 3.50 \\
\hline 3 & 7 & 3.83 & 5.00 & 3.33 & 2.67 & 4.00 \\
\hline 3 & 9 & 3.50 & 4.00 & 3.67 & 4.00 & 3.50 \\
\hline 3 & 11 & 3.00 & 3.67 & 3.50 & 3.00 & 3.33 \\
\hline 3 & 12 & 4.00 & 3.50 & 3.83 & 3.83 & 4.00 \\
\hline 3 & 15 & 3.67 & 4.33 & 4.00 & 4.00 & 3.33 \\
\hline 4 & 16 & 3.50 & 5.00 & 5.00 & 3.00 & 3.83 \\
\hline 4 & 21 & 3.00 & 4.00 & 4.00 & 2.83 & 4.00 \\
\hline 4 & 25 & 2.83 & 4.16 & 4.00 & 3.17 & 3.17 \\
\hline 4 & 26 & 3.33 & 4.83 & 4.17 & 3.83 & 3.83 \\
\hline 4 & 33 & 3.50 & 4.33 & 4.33 & 4.00 & 3.33 \\
\hline 5 & 10 & 4.33 & 4.33 & 4.00 & 3.00 & 3.83 \\
\hline 5 & 22 & 2.50 & 2.50 & 3.67 & 2.83 & 3.50 \\
\hline 5 & 34 & 2.33 & 3.33 & 2.33 & 2.17 & 3.00 \\
\hline 5 & 35 & 2.33 & 2.83 & 2.83 & 2.83 & 2.83 \\
\hline
\end{tabular}

* All leaders were presented with 30 statements, six each for the five personality constructs, to rate him/herself on a five point response scale ranging from 1(Strongly disagree) to 5 (Strongly agree). Highest score on a personality construct is assumed as the dominant personality type of the leader.

Table 8. Descriptive statistics of big five personality scores of leaders in the sample

\begin{tabular}{|c|c|c|c|c|}
\hline & Mean & Median & $\begin{array}{c}\text { Std. } \\
\text { Deviation }\end{array}$ & Variance \\
\hline Extraversion & 3.21 & 3.17 & 0.48 & 0.23 \\
\hline Conscientiousness & 3.97 & 4.16 & 0.80 & 0.64 \\
\hline Agreeableness & 3.50 & 3.67 & 0.65 & 0.42 \\
\hline Emotional Stability & 3.17 & 3.00 & 0.49 & 0.24 \\
\hline $\begin{array}{c}\text { Openness to } \\
\text { Experience }\end{array}$ & 3.22 & 3.33 & 0.56 & 0.31 \\
\hline
\end{tabular}

*All the personality constructs lie on the upper end for mean and median. The variation is comparatively high for conscientiousness whereas the rest of the constructs lie close to the mean due to low variance.

Leadership style 1 leans towards autocracy and high task-orientation. Followers are explicitly given instructions for achievement of specified goals. LS1 is the dominant leadership style of leader 17, 18, 19, 23, 28, 30 and 32 belonging to same kind of organizations. All leaders scored high on conscientiousness and moderately low on openness to experience. Thus it can be maintained that these leaders are highly reliable and prefer status quo. Moreover, leaders with LS1 fell between moderately high to high on extraversion and agreeableness. However, leaders ranged between moderately low to moderately high on emotional stability. Thus, results of all leaders show that LS1 consistently relates to high conscientiousness, moderately high extraversion and agreeableness and moderately low openness to experience.

Leadership style 2 is characterized by participation, employee focus and shared decision making. LS2 is the dominant leadership style of eight leaders out of the sample of 35 who belonged to different type of firms. All the leaders 
scored moderately high to high on extraversion, emotional stability and openness to experience. In rest of the two personality constructs, the results lacked consistency in that few leaders fell in the same range whereas others output range completely differed. Thus, results of all leaders with LS2 show that LS2 consistently relates to high extraversion, emotional stability and openness to experience.

Leaders with leadership style 3 are visionaries and make use of shared decision making persuading their subordinates to believe in their vision and strategy. This was the most prominent leadership style of the sample as 11 leaders had LS3 as their dominant leadership style. Consistent results were also found in conscientiousness as all leaders rated very high on this trait with an exception of only one. The 11 leaders have moderately high to high scores on extraversion, agreeableness, emotional stability and openness to experience. Thus, results of all eleven leaders show that LS3 is consistently related to all personality traits among which high conscientiousness is the dominant trait.

Leadership style 4 is characterized by stewardship, assisting subordinates and making decisions in their interest. Subordinates are encouraged to achieve level of self-fulfillment with the guidance of the leader. 5 participants out of the sample of 35 had LS4 among which 4 ran their own charity school system and fifth had initiated his microfinance organization that lent to the poor without interest charges. The leaders scored very high on conscientiousness and agreeableness and moderately high to high on extraversion, emotional stability and openness to experience. The results of the leader depicts that LS4 is related to high conscientiousness and agreeableness and moderately high with the rest of the personality traits.

Leadership style 5 is considered being devoid of leadership as the leader does not exercise his leadership. Followers are mostly frustrated and unmotivated under this kind of leadership. Only 4 leaders out of the sample of 35 had leadership style 5 , two of which belonged to organizations which had been operating since one year only. Three out of four leaders scored moderately low on extraversion and one rated high on it. All four rated moderately high to high on openness to experience and moderately low to moderately high on emotional stability. However, on the remaining two personality constructs the results were varied considerably. Thus, the leaders deem themselves to be open. However, the subordinates may have attributed LS5 as their style due to their low extraversion and emotional stability. The results of the leaders with LS5 depict that LS5 consistently relates to moderately low extraversion and moderately high openness to experience. The consistency of results can't be maintained for other three personality constructs. However, results of LS5 need further probation due to availability of only four cases with this particular leadership style.

\section{Conclusions}

Fascination with leadership with regard to determining the predictors of effective leadership has and will continue to interest researchers. The past literature lacks a framework for developing symbolic leadership styles which are needed in order to link leadership with structured frame of references such as the personality traits advanced by the big five model. The personality literature witnessed a similar dilemma at the beginning of the research on personality traits when large number of personality traits were identified among which only few were found consistent in different cases. However, the problem was resolved when extensive research on the subject eliminated the need to use several traits and instead formulate symbolic personality traits which were advanced by the big five model. The discussion on leadership, in contrast, remains scattered which makes it impossible to effectively link the discussion on leadership styles with personality dimensions. This research study has added to the anthology of leadership-personality literature by determining if personality traits can predict leadership styles of leaders by formulating and using representative leadership styles.

The several leadership styles scattered in the voluminous leadership literature were identified and grouped in five groups based on their common characteristics. Such an effort was conducted to identify the mutually exclusive areas to streamline the discussion on this topic. The thirty-nine leadership styles found in the literature search were amalgamated in 5 representative styles to present a more practical configuration of leadership and fill the void in the leadership literature which needs culmination into symbolic leadership styles. Also, since the personality research is well structured and has suitably culminated into symbolic personality traits proposed by the big five model, it was reasonable to identify the symbolic leadership styles prior to relating a structured personality framework with unstructured leadership styles.

The study was able to explore association of representative leadership styles with personality traits and support the long standing thesis that personality has an impact on leader's effectiveness (Hogan et al. [130]; Anderson [2]).The findings suggest that leadership styles are to some extent associated with personality types. Personality has an impact on the leadership style of the leaders and, thus, should be considered while examining the effectiveness of leadership. However, precise impact of personality needs to be further examined. In this study, association of LS1 and LS3 with high conscientiousness and LS2 with high extraversion, emotional stability and openness to experience is significant but the results of rest of the leadership styles cannot be generalized due to small sample size.

\section{Implications}

This study has systematically endeavored to link the personality traits with the leadership styles; however, it is recommended that further research be conducted to probe into linking the personality with leadership by using representative in lieu of existing scattered leadership styles. 
This would help researchers and practitioners see a better and organized shape of leadership styles grouped in five distinct dimensions. Further research in this direction can not only include additional dimensions but also add to existing dimensions by bringing in more leadership styles under the existing framework. Managerial implications of study include selecting right type of leaders for relevant jobs through personality test as well as developing leaders for the future. Nowadays, significant number of organizations utilize personality tests for the recruitment of managers. However, the traces of personality test with the leadership requirements of future are rarely considered. The findings of study will help to fine tune the managerial induction according to the leadership requirements of organization in future.

\section{REFERENCES}

[1] Johnson, A. M., Vernon, P. A., McCarthy, J. M., Molson, M., Harris, J. A., \& Jang, K. L. (1998). Nature vs nurture: Are leaders born or made? A behavior genetic investigation of leadership style. Twin research, 1, 216-223. doi: 10.1375/twin.1.4.216.

[2] Anderson, J. A. (2006). Leadership, personality and effectiveness. The Journal of Socio-Economics, 35, 10781091. doi: 10.1016/j.socec.2005.11.066.

[3] De Hoogh, A. H., Den Hartog, D. N., \& Koopman, P. L. (2005). Linking the Big Five - Factors of personality to charismatic and transactional leadership; perceived dynamic work environment as a moderator. Journal of Organizational Behavior, 26, 839-865. doi: 10.1002/job.344.

[4] Kirkpatick, S. A., \& Locke, E. A. (1991). Leadership: do traits matter?. The executive, 5, 48-60. doi: 10.5465/AME.1991.4274679.

[5] Rowley, J. (1997). Academic leaders: made or born? Industrial and Commercial Training, 29, 78-84. doi: 10.1108/00197859710165065.

[6] Ruvolo, C. M., Peterson, S. A., \& LeBoeuf, J. N. (2004). Leaders Are Made, Not Born $<\mathrm{em}>$ The Critical Role of a Developmental Framework to Facilitate an Organizational Culture of Development $</ \mathrm{em}>$. Consulting psychology journal: practice and research, 56, 10-19. doi: 10.1037/1061-4087.56.1.10.

[7] Marques, J. F. (2010). Awakened leaders: born or made?. Leadership \& Organization Development Journal, 31, 307-323. doi: 10.1108/01437731011043339.

[8] Van Eeden, R., Cilliers, F., \& Van Deventer, V. (2008). Leadership styles and associated personality traits: Support for the conceptualisation of transactional and transformational leadership. South African Journal of Psychology, 38, 253-267. doi: $10.1177 / 008124630803800201$.

[9] Zopiatis, A., \& Constanti, P. (2012). Extraversion, openness and conscientiousness: The route to transformational leadership in the hotel industry. Leadership \& Organization
Development Journal, 33, 86-104. doi: $10.1108 / 01437731211193133$.

[10] Judge, T. A., \& Bono, J. E. (2000). Five-factor model of personality and transformational leadership. Journal of applied psychology, $85,751-765$. doi: 10.1037/0021-9010.85.5.751.

[11] Muczyk, J. P., \& Reimann, B. C. (1987). The case for directive leadership. The Academy of Management Executive, 1, 301-311. doi: 10.5465/AME.1987.4275646.

[12] Gini, A. (1997). Moral leadership: An overview. Journal of Business Ethics, 16, 323-330. doi: 10.1023/A:1017959915472.

[13] De Vries, M. F. K. (1994). The leadership mystique. The Academy of Management Executive, 8, 73-89. doi: 10.5465/AME.1994.9503101181.

[14] Bass, B. M., \& Bass, R. (2009). The Bass handbook of leadership: Theory, research, and managerial applications. New York,NY: Simon and Schuster

[15] Gardner, J. W. (1990). On Leadership. New York, USA: The Free Press.

[16] Burns, J. M. (1978). Leadership. New York, NY: Harper \& Row.

[17] Jago, A. G. (1982). Leadership: Perspectives in theory and research. Management science, 28, 315-336. doi: 10.1287/mnsc.28.3.315

[18] Stogdill, R. M. (1974). Handbook of leadership: A survey of theory and research. New York, NY: Free Press.

[19] Yukl, G. (2009). Leadership in Organizations. New Delhi: Dorling Kindersley.

[20] Van Vugt, M., Jepson, S. F., Hart, C. M., \& De Cremer, D. (2004). Autocratic leadership in social dilemmas: A threat to group stability. Journal of Experimental Social Psychology, 40, 1-13. doi:10.1016/S0022-1031(03)00061-1.

[21] De Cremer, D. (2006). Affective and motivational consequences of leader self-sacrifice: The moderating effect of autocratic leadership. The Leadership Quarterly, 17, 79-93. doi: 10.1016/j.leaqua.2005.10.005.

[22] Gastil, J. (1994). A definition and illustration of democratic leadership. Human Relations, 47, 953-975. doi: $10.1177 / 001872679404700805$.

[23] Foels, R., Driskell, J. E., Mullen, B., \& Salas, E. (2000). The effects of democratic leadership on group member satisfaction an integration. Small Group Research, 31, 676-701. doi: 10.1177/104649640003100603.

[24] Rok, B. (2009). Ethical context of the participative leadership model: taking people into account. Corporate Governance, 9, 461-472. doi: 10.1108/14720700910985007.

[25] Huang, X., Iun, J., Liu, A., \& Gong, Y. (2010). Does participative leadership enhance work performance by inducing empowerment or trust? The differential effects on managerial and non - managerial subordinates. Journal of Organizational Behavior, 31, 122-143. doi: 10.1002/job.636.

[26] Pearce, C. L., \& Sims Jr, H. P. (2002). Vertical versus shared leadership as predictors of the effectiveness of change management teams: An examination of aversive, directive, 
transactional, transformational, and empowering leader behaviors. Group dynamics: Theory, research, and practice, 6 , 172-197. doi:10.1037/1089-2699.6.2.172.

[27] Tabernero, C., Chambel, M. J., Curral, L., \& Arana, J. M. (2009). The role of task-oriented versus relationship-oriented leadership on normative contract and group performance. Social Behavior and Personality: an international journal, 37, 1391-1404. doi: 10.2224/sbp.2009.37.10.1391.

[28] Yukl, G. (2012). Effective Leadership Behavior: What We Know and What Questions Need More Attention. The Academy of Management Perspectives, 26, 66-85. doi: 10.5465/amp.2012.0088.

[29] Bass, B. M., Avolio, B. J., Jung, D. I., \& Berson, Y. (2003). Predicting unit performance by assessing transformational and transactional leadership. Journal of Applied Psychology, 88, 207-218. doi: 10.1037/0021-9010.88.2.207.

[30] Eagly, A. H., Johannesen-Schmidt, M. C., \& Van Engen, M. L. (2003). Transformational, transactional, and laissez-faire leadership styles: a meta-analysis comparing women and men. Psychological bulletin, 129, 569. doi: 10.1037/0033-2909.129.4.569.

[31] Bass, B. M. (1997). Does the transactional-transformational leadership paradigm transcend organizational and national boundaries?. American Psychologist, 52, 130. doi: 10.1037/0003-066X.52.2.130.

[32] Hunt, J. G. (1999). Transformational/charismatic leadership's transformation of the field: An historical essay. The Leadership Quarterly, 10, 129-144. doi: 10.1016/S1048-9843(99)00015-6.

[33] Jung, D. I., \& Avolio, B. J. (2000). Opening the black box: An experimental investigation of the mediating effects of trust and value congruence on transformational and transactional leadership. Journal of organizational Behavior, 21, 949-964. doi:

10.1002/1099-1379(200012)21:8<949::AID-JOB64>3.0.CO ;2-F.

[34] Skogstad, A., Einarsen, S., Torsheim, T., Aasland, M. S., \& Hetland, H. (2007). The destructiveness of laissez-faire leadership behavior. Journal of occupational health psychology, 12, 80-92. doi: 10.1037/1076-8998.12.1.80.

[35] Yukl, G. (1999). An evaluation of conceptual weaknesses in transformational and charismatic leadership theories. The leadership quarterly, $10, \quad 285-305$. doi: 10.1016/S1048-9843(99)00013-2

[36] Stone, A. G., Russell, R. F., \& Patterson, K. (2004). Transformational versus servant leadership: A difference in leader focus. Leadership \& Organization Development Journal, 25, 349-361. doi: 10.1108/01437730410538671.

[37] Beazley, D., \& Gemmill, G. (2006). Spirituality and Servant Leader Behavior. Journal of Management, Spirituality \& Religion, 3, 258-270. doi: 10.1080./14766080609518629.

[38] Pekerti, A. A., \& Sendjaya, S. (2010). Exploring servant leadership across cultures: comparative study in Australia and Indonesia. The International Journal of Human Resource Management, 21, 754-780. doi:

10.1080/09585191003658920.

[39] Russell, R. F., \& Stone, A. G. (2002). A review of servant leadership attributes: Developing a practical model. Leadership \& Organization Development Journal, 23, 145-157. doi:10.1108/01437730210424.

[40] Woods, P. A. (2004). Democratic leadership: drawing distinctions with distributed leadership. International Journal of Leadership in Education, 7, 3-26. doi: $10.1080 / 1360312032000154522$.

[41] Eagly, A. H., \& Johnson, B. T. (1990). Gender and leadership style: A meta-analysis. Psychological bulletin, 108, 233-256. doi: 10.1037/0033-2909.108.2.233.

[42] Fleming, R. K. (1992). An integrated behavioral approach to transfer of interpersonal leadership skills. Journal of Management Education, 16, 341-353. doi: $10.1177 / 105256299201600306$.

[43] Zander, L. (1997). The license to lead: An 18 country study of the relationship between employees' preferences regarding interpersonal leadership and national culture. Stockholm, Institute of International Business (IIB): Stockholm School of Economics.

[44] Brodbeck, F. C., Frese, M., Akerblom, S., Audia, G., Bakacsi, G., Bendova, H., \& Wunderer, R. (2000). Cultural variation of leadership prototypes across 22 European countries. Journal of Occupational and Organizational Psychology, 73, 1-29. doi: 10.1348/096317900166859.

[45] Avolio, B. J., Bass, B. M., \& Jung, D. I. (1999). Re examining the components of transformational and transactional leadership using the Multifactor Leadership. Journal of occupational and organizational psychology, 72, 441-462. doi: 10.1348/096317999166789.

[46] Gronn, P. (2002). Distributed leadership as a unit of analysis. The leadership quarterly, 13, 423-451. doi: 10.1016/S1048-9843(02)00120-0.

[47] Mehra, A., Smith, B. R., Dixon, A. L., \& Robertson, B. (2006). Distributed leadership in teams: The network of leadership perceptions and team performance. The Leadership Quarterly, 17, 232-245. doi: 10.1016/j.leaqua.2006.02.003.

[48] Mayrowetz, D. (2008). Making sense of distributed leadership: Exploring the multiple usages of the concept in the field. Educational Administration Quarterly, 44, 424-435. doi: 10.1177/0013161X07309480.

[49] Kahai, S. S., Sosik, J. J., \& Avolio, B. J. (2004). Effects of participative and directive leadership in electronic groups. Group \& Organization Management, 29, 67-105. doi: 10.1177/1059601103252100.

[50] Walumbwa, F. O., Mayer, D. M., Wang, P., Wang, H., Workman, K., \& Christensen, A. L. (2011). Linking ethical leadership to employee performance: The roles of leadermember exchange, self-efficacy, and organizational identification. Organizational Behavior and Human Decision Processes, 115, 204-213. doi: 10.1016/j.obhdp.2010.11.002.

[51] Brown, M. E., \& Treviño, L. K. (2006). Ethical leadership: A review and future directions. The Leadership Quarterly, 17, 595-616. doi: 10.1016/j.leaqua.2006.10.004.

[52] Toor, S. U. R., \& Ofori, G. (2009). Ethical Leadership: Examining the Relationships with Full Range Leadership Model, Employee Outcomes, and Organizational Culture. Journal of Business Ethics, 90, 533-547.doi: 


\subsection{7/s10551-009-0059-3.}

[53] Martin, A. J. (2005). The role of positive psychology in enhancing satisfaction, motivation, and productivity in the workplace. Journal of Organizational Behavior Management, 24, 113-133. doi: 10.1300/J075v24n01_07.

[54] Dinham, S. (2007). Authoritative leadership, action learning and student accomplishment. Available online http://research.acer.edu.au/research_conference_2007/3/.

[55] Pellegrini, E. K., \& Scandura, T. A. (2008). Paternalistic leadership: A review and agenda for future research. Journal of Management, 34, 566-593. doi: $10.1177 / 0149206308316063$

[56] Kiazad, K., Restubog, S. L. D., Zagenczyk, T. J., Kiewitz, C., \& Tang, R. L. (2010). In pursuit of power: The role of authoritarian leadership in the relationship between supervisors' Machiavellianism and subordinates' perceptions of abusive supervisory behavior. Journal of Research in Personality, 44, 512-519. doi:10.1016/j.jrp.2010.06.004.

[57] Dealtry, R. (2001). Managing intellectual leadership in corporate value. Journal of Workplace Learning, 13, 119-124. doi: 10.1108/13665620110388424.

[58] Andreasen, A. R. (2005). Marketing scholarship, intellectual leadership, and the zeitgeist. Journal of Public Policy \& Marketing, 24, 133-136. doi: 10.1509/jppm.24.1.133.63892.

[59] Versi, A. (2013, March 20). Taking the intellectual leadership on Africa. African Business. Available online $\mathrm{http}: / /$ africanbusinessmagazine.com/management/taking-theintellectual-leadership-on-africa/.

[60] Rossel, R. D. (1970). Instrumental and expressive leadership in complex organizations. Administrative Science Quarterly, 15, 306-316. doi: $10.2307 / 2391620$.

[61] Rees, C. R., \& Segal, M. W. (1984). Role Differentiation In Groups The Relationship Between Instrumental and Expressive Leadership. Small Group Research, 15, 109-123. doi: $10.1177 / 104649648401500106$.

[62] Southworth, G. (1993). School leadership and school development: reflections from research. School Organization, 13, 73-87. doi: 10.1080/0260136930130107.

[63] Spector, P. E. (1982). Behavior in organizations as a function of employee's locus of control. Psychological bulletin, 91, 482-497. doi: 10.1037/0033-2909.91.3.482.

[64] Goleman, D. (2000). Leadership that gets results. Harvard business review, 78(2), 78-93.

[65] Skodvin, T., \& Andresen, S. (2006). Leadership revisited. Global Environmental Politics, 6, 13-27. doi:10.1162/glep.2006.6.3.13.

[66] Kezar, A. (1998). Trying Transformations: Implementing Team - Oriented Forms of Leadership. New directions for institutional research, 1998, 57-72. doi: 10.1002/ir.10005.

[67] Javidan, M., Dorfman, P. W., De Luque, M. S., \& House, R. J. (2006). In the eye of the beholder: Cross cultural lessons in leadership from Project GLOBE. The Academy of Management $\quad$ Perspectives, 67-90. doi:10.5465/AMP.2006.19873410

[68] Day, D. V., Gronn, P., \& Salas, E. (2006). Leadership in team-based organizations: On the threshold of a new era. The Leadership Quarterly, 17, 211-216. doi: 10.1016/j.leaqua.2006.02.001.

[69] Leana, C. R. (1986). Predictors and consequences of delegation. Academy of Management Journal, 29, 754-774. doi: $10.2307 / 255943$.

[70] Kuhnert, K. W. (1994). Transforming leadership: Developing people through delegation. Thousand Oaks, CA: Sage.

[71] Krause, D. E., Gebert, D., \& Kearney, E. (2007). Implementing Process Innovations The Benefits of Combining Delegative-Participative With Consultative-Advisory Leadership. Journal of Leadership \& Organizational Studies, 14, 16-25. doi: $10.1177 / 1071791907304224$

[72] Elloy, D. F. \& Alan, R. (1997). The Effect of Superleader Behavior on Autonomous Work Groups in a Government Operated Railway Service. Public Personnel Management, 26(2), 257-272.

[73] Taggar, S., HACKEW, R., \& Saha, S. (1999). Leadership emergence in autonomous work teams: Antecedents and outcomes. Personnel Psychology, 52, 899-926. doi: 10.1111/j.1744-6570.1999.tb00184.x.

[74] Patanakul, P., Chen, J., \& Lynn, G. S. (2012). Autonomous teams and new product development. Journal of Product Innovation Management, 29, 734-750. doi: 10.1111/j.1540-5885.2012.00934.x.

[75] Hicks, R., \& McCracken, J. (2011). Coaching as a leadership style. Physician executive, 37(5), 70-72.

[76] Nyman, M., \& Thach, L. (2002). Coaching as a new leadership development option. Supervision, 63(9), 23-26.

[77] Robertson, J. (2009). Coaching leadership learning through partnership. School Leadership and Management, 29, 39-49. doi: $10.1080 / 13632430802646388$.

[78] Goleman, D., Boyatzis, R., \& Mckee, A. (2002). Primal leadership: realizing the power of emotional intelligence. Harvard Business School Press, USA

[79] Bennis, W. (2003). The emotionally intelligent workplace: How to select for, measure, and improve emotional intelligence in individuals, groups, and organizations. C. Cherniss, \& D. Goleman (Eds.). San Francisco: John Wiley \& Sons.

[80] Rafferty, A. E., \& Griffin, M. A. (2006). Refining individualized consideration: Distinguishing developmental leadership and supportive leadership. Journal of occupational and organizational psychology, 79, 37-61. doi: $10.1348 / 096317905 X 36731$.

[81] Muller, J., Maclean, R., \& Biggs, H. (2009). The impact of a supportive leadership program in a policing organisation from the participants' perspective. Work: A Journal of Prevention, Assessment and Rehabilitation, 32, 69-79. doi: 10.3233/WOR-2009-0817.

[82] Schyns, B., van Veldhoven, M., \& Wood, S. (2009). Organizational climate, relative psychological climate and job satisfaction: The example of supportive leadership climate. Leadership \& Organization Development Journal, 30, 649-663. doi: 10.1108/01437730910991664.

[83] Yousef, D. A. (2000). Organizational commitment: A 
mediator of the relationships of leadership behavior with job satisfaction and performance in a non-western country. Journal of Managerial Psychology, 15, 6-24. doi: 10.1108/02683940010305270.

[84] Selart, M. (2005). Understanding the role of locus of control in consultative decision-making: a case study. Management Decision, 43, 397-412. doi: 10.1108/00251740510589779.

[85] Brodbeck, F. C., Frese, M., \& Javidan, M. (2002). Leadership made in Germany: Low on compassion, high on performance. The Academy of Management Executive, 16, 16-29. doi: 10.5465/AMR.2002.6640111.

[86] Winston, B. E., \& Ryan, B. (2008). Servant leadership as a humane orientation: Using the GLOBE study construct of humane orientation to show that servant leadership is more global than western. International Journal of Leadership Studies, 3(2), 212-222

[87] Paris, L. D., Howell, J. P., Dorfman, P. W., \& Hanges, P. J. (2009). Preferred leadership prototypes of male and female leaders in 27 countries. Journal of International Business Studies, 40, 1396-1405. doi: 10.1057/jibs.2008.114.

[88] Westley, F., \& Mintzberg, H. (1989). Visionary leadership and strategic management. Strategic management journal, 10, 17-32. doi: 10.1002/smj.4250100704.

[89] Brown, K. M., \& Anfara, V. A. (2003). Paving the way for change: Visionary leadership in action at the middle level. Nassp Bulletin, 87, 16-34. doi: $10.1177 / 019263650308763503$.

[90] Groves, K. S. (2006). Leader emotional expressivity, visionary leadership, and organizational change. Leadership \& Organization Development Journal, 27, 566-583.doi:10.1108/01437730610692425.

[91] [91]Giritli, H., \& Oraz, G. T. (2004). Leadership styles: some evidence from the Turkish construction industry. Construction Management and Economics, 22, 253-262. doi: $10.1080 / 01446190310001630993$.

[92] Rosenthal, S. A., \& Pittinsky, T. L. (2006). Narcissistic leadership. The Leadership Quarterly, 17, 617-633. doi: 10.1016/j.leaqua.2006.10.005.

[93] Brunell, A. B., Gentry, W. A., Campbell, W. K., Hoffman, B. J., Kuhnert, K. W., \& DeMarree, K. G. (2008). Leader emergence: The case of the narcissistic leader. Personality and Social Psychology Bulletin, 34, 1663-1676. doi: $10.1177 / 0146167208324101$

[94] Ouimet, G. (2010). Dynamics of narcissistic leadership in organizations: Towards an integrated research model. Journal of Managerial Psychology, 25, 713-726. doi: $10.1108 / 02683941011075265$.

[95] Avolio, B. J., Kahai, S., \& Dodge, G. E. (2001). E-leadership: Implications for theory, research, and practice. The Leadership Quarterly, 11, 615-668. doi: 10.1016/S1048-9843(00)00062-X.

[96] Pulley, M. L., \& Sessa, V. I. (2001). E-leadership: tackling complex challenges. Industrial and Commercial Training, 33, 225-230. doi: 10.1108/00197850110405379.

[97] Gurr, D. (2004). ICT, Leadership in Education and E leadership. Discourse: studies in the cultural politics of education, 25, 113-124. doi:

\section{$10.1080 / 0159630042000178518$.}

[98] Griffin, R. W. (1980). Relationships among individual, task design, and leader behavior variables. Academy of Management Journal, 23, 665-683. doi: 10.2307/255555.

[99] Dragoni, L. (2005). Understanding the emergence of state goal orientation in organizational work groups: the role of leadership and multilevel climate perceptions. Journal of Applied Psychology, 90, 1084-1113. doi: 10.1037/0021-9010.90.6.1084

[100] Müller, R., \& Turner, R. (2010). Leadership competency profiles of successful project managers. International Journal of Project Management, 28, 437-448. doi: 10.1016/j.ijproman.2009.09.003.

[101] Avolio, B. J., \& Gardner, W. L. (2005). Authentic leadership development: Getting to the root of positive forms of leadership. The leadership quarterly, 16, 315-338. doi: 10.1016/j.leaqua.2005.03.001.

[102] Cooper, C. D., Scandura, T. A., \& Schriesheim, C. A. (2005). Looking forward but learning from our past: Potential challenges to developing authentic leadership theory and authentic leaders. The Leadership Quarterly, 16, 475-493. doi: 10.1016/j.leaqua.2005.03.008.

[103] Hannah, S. T., Avolio, B. J., \& Walumbwa, F. O. (2011). Relationships between authentic leadership, moral courage, and ethical and pro-social behaviors. Business Ethics Quarterly, 21, 555-578. doi: 10.5840/beq201121436.

[104] Perreault, G. E. (1997). Citizen leader: A community service option for college students. NASPA Journal, 34(2), 147-156.

[105] Langone, C. A. (2004). The use of a citizen leader model for teaching strategic leadership. Journal of Leadership Education, 3, 82-88. doi: 10.12806/V3/I1/AB3.

[106] Booker, S. L. (2006). From the classroom to the council chamber: How town - gown collaborations can support citizen leadership. National Civic Review, 95, 37-42. doi: $10.1002 /$ ncr. 156

[107] Bligh, M. C., Kohles, J. C., Pearce, C. L., Justin, J. E., \& Stovall, J. F. (2007). When the romance is over: Follower perspectives of aversive leadership. Applied Psychology, 56, 528-557. doi: 10.1111/j.1464-0597.2007.00303.x.

[108] Thoroughgood, C. N., Hunter, S. T., \& Sawyer, K. B. (2011). Bad apples, bad barrels, and broken followers? An empirical examination of contextual influences on follower perceptions and reactions to aversive leadership. Journal of business ethics, 100, 647-672. doi: 10.1007/s10551-010-0702-z.

[109] Sims Jr, H. P., Faraj, S., \& Yun, S. (2009). When should a leader be directive or empowering? How to develop your own situational theory of leadership. Business Horizons, 52, 149-158. doi: 10.1016/j.bushor.2008.10.002.

[110] Vecchio, R. P., Justin, J. E., \& Pearce, C. L. (2010). Empowering leadership: An examination of mediating mechanisms within a hierarchical structure. The Leadership Quarterly, 21, 530-542. doi:10.1016/j.leaqua.2010.03.014.

[111] Martin, S. L., Liao, H., \& Campbell, E. M. (2013). Directive versus Empowering Leadership: A Field Experiment Comparing Impacts on Task Proficiency and Proactivity. Academy of Management Journal, 56, 1372-1395. doi:10.5465/amj.2011.0113. 
[112] Robertson, T. S., \& Myers, J. H. (1969). Personality correlates of opinion leadership and innovative buying behavior. Journal of Marketing Research, 6, 164-168. doi: $10.2307 / 3149667$.

[113] Myers, J. H., \& Robertson, T. S. (1972). Dimensions of opinion leadership. Journal of Marketing Research, 9, 41-46. doi: $10.2307 / 3149604$.

[114] Chan, K. K., \& Misra, S. (1990). Characteristics of the opinion leader: A new dimension. Journal of Advertising, 19, 53-60. doi: 10.1080/00913367.1990.10673192.

[115] Boyatzis, R. E., Goleman, D., \& Rhee, K. (2000). Clustering competence in emotional intelligence: Insights from the Emotional Competence Inventory (ECI). Handbook of emotional intelligence, 343-362. Available online www.eiconsortium.org/pdf/eci_acticle.pdf.

[116] Winter, D. G. (1991). A motivational model of leadership: Predicting long-term management success from TAT measures of power motivation and responsibility. The Leadership Quarterly, 2, 67-80. doi: 10.1016/1048-9843(91)90023-U.

[117] McCall Jr., M. W. \& Lombardo., M.M. (1983). "What Makes A Top Executive? Two Behavioral Scientists From A Leading Think Tank Map The Pitfalls Along The Path To The Executive Suite." Army Organizational Effectiveness Journal 8(1): 51-55. Available online http://armyoe.com/uploads/1984_vol8_number1.pdf\#page=5 4.

[118] Kaiser, R. B., \& Hogan, J. (2011). Personality, leader behavior, and overdoing it. Consulting Psychology Journal: Practice and Research, 63, 219- 242 .doi: 10.1037/a0026795.

[119] Ng, K. Y., Ang, S., \& Chan, K. Y. (2008). Personality and leader effectiveness: a moderated mediation model of leadership self-efficacy, job demands, and job autonomy. Journal of Applied Psychology, 93, 733-743. doi:10.1037/0021-9010.93.4.733.

[120] Judge, T. A., Bono, J. E., Ilies, R., \& Gerhardt, M. W. (2002). Personality and leadership: a qualitative and quantitative review. Journal of applied psychology, 87, 765-780. doi: 10.1037//0021-9010.87.4.765.

[121] Wiggins, J. S., \& Trapnell, P. D. (1997). Personality structure: The return of the big five. doi:10.1016/B978-012134645-4/50029-9.

[122] John, O. P., Angleitner, A., \& Ostendorf, F. (1988). The lexical approach to personality: A historical review of trait taxonomic research. European journal of Personality, 2, 171-203. doi: 10.1002/per.2410020302.

[123] Digman, J. M. (1989). Five robust trait dimensions: Development, stability, and utility. Journal of Personality, 57, 195-214. doi: 10.1111/j.1467-6494.1989.tb00480.x.

[124] Digman, J. M. (1990). Personality structure: Emergence of the five-factor model. Annual Review of Psychology, 41, 417-440. doi: 10.1146/annurev.ps.41.020190.002221.

[125] Rushton, J. P., \& Irwing, P. (2009). A general factor of personality in 16 sets of the Big Five, the GuilfordZimmerman Temperament Survey, the California Psychological Inventory, and the Temperament and Character Inventory. Personality and Individual Differences, 47, 558-564. doi: 10.1016/j.paid.2009.05.009.

[126] Houghton, J. D., Bonham, T. W., Neck, C. P., \& Singh, K. (2004). The relationship between self-leadership and personality: A comparison of hierarchical factor structures. Journal of Managerial Psychology, 19, 427-441. doi:10.1108/02683940410537963.

[127] Crant, J. M., \& Bateman, T. S. (2000). Charismatic leadership viewed from above: The impact of proactive personality. Journal of organizational Behavior, 21, 63-75. doi: 10.1002/(SICI)1099-1379(200002)21:1<63::AID-JOB8>3.0. CO;2-J.

[128] Cable, D. M., \& Judge, T. A. (2003). Managers' upward influence tactic strategies: The role of manager personality and supervisor leadership style. Journal of Organizational Behavior, 24, 197-214. doi: 10.1002/job.183.

[129] Sorenson, G. J., Goethals, G. R., \& MacGregor Burns, J. (Eds.). (2004). Encyclopedia of Leadership. New Delhi: Sage.

[130] Perrewé, P. L., \& Spector, P. E. (2002). Personality research in the organizational sciences. Research in personnel and human resources management, 21, 1-63. doi: 10.1016/S0742-7301(02)21001-4.

[131] Barrick, M. R., \& Mount, M. K. (1991). The big five personality dimensions and job performance: a meta analysis. Personnel psychology, 44, 1-26. doi: 10.1111/j.1744-6570.1991.tb00688.x.

[132] Hogan, R., Curphy, G. J., \& Hogan, J. (1994). What we know about leadership: Effectiveness and personality. American Psychologist, 49, 493-504. doi: 10.1037/0003-066X.49.6.493. 